\title{
BULLETIN
}

OF THE

SCHOOL OF

ORIENTAL AND

AFRICAN STUDIES

UNIVERSITY OF LONDON 


\title{
BULLETIN
}

OF THE

\section{SCHOOL OF \\ ORIENTAL AND \\ AFRICAN STUDIES}

UNIVERSITY OF LONDON

\author{
Published by
}

THE SCHOOL OF ORIENTAL AND AFRICAN STUDIES

Agents: Messrs. Luzac \& Co., I.td., 46 Great Russell Street, W.C.1 
(C) School of Oriental and African Studies

University of London

\section{MANCHESTER} UNIVERSITY LIBRARY

Printed in England by Stephen Austin and Sons, Ltd., Caxton Hill, Hertford 


\section{CONTENTS}

ARTICLES AND NOTES AND COMMUNICATIONS

PAGE

D. L. Appleyard: /a-/ and /as-/ verb forms in Amharic

S. ArIEL: The functions of the conjugations in Colloquial Israeli Hebrew

J. BLAU : Middle and Old Arabic material for the history of stress in Arabic .

T. Burrow : A reconsideration of Fortunatov's law _ . . . $\quad 531$

M. G. Carter : 'Twenty dirhams' in the Kitāb of Sỉbawaihi . $\quad 485$

A. C. Graham : The Classical Chinese topic-marker $f u$ 夫 . . 85

HaIlu Fulass : On Amharic relative clauses _ . . . . 497

Robert Hetzron : The shape of a rule and diachrony . . . . 451

Louis JAcoBs : The qal va-homer argument in the Old Testament . 221

PadmanabH S. JaIni : The $\bar{A} l o k \bar{a}$ of Haribhadra and the Sāratamā of Ratnākaraśānti : a comparative study of the two commentaries of the Astasāhasrikā

271

T. M. Johnstone : The language of poetry in Dhofar . . . . 1

D. N. MacKenzie : The Khwarezmian glossary-V . . . . 56

J. R. MarR : The Kuṭumiyāmalai music inscription . . . . 615

Rex S. O'Fahey and JAY L. Spaulding : Hāshim and the Musabba‘àt 316

M. C. Ricklefs : A consideration of three versions of the Babad tanah Djawi, with excerpts on the fall of Madjapahit .

Stuart R. Schram : Some recent studies of revolutionary movements in China in the early twentieth century . . . . . . 588

J. B. SegaL : The church of St. George at Urfa (Edessa) . $\quad 606$

A. Shapur Shahbazi : The 'one year' of Darius re-examined . 609

S. V. Shanmugam : Dental and alveolar nasals in Dravidian . . 74

WALTER SImon: An incomplete copy of a sūtra incorporated in the Peking print of the Tibetan Kanjur

Nicholas Sims-Williams : A Sogdian ideogram . . . . . 614

R. K. Sprigg: A polysystemic approach, in Proto-Tibetan reconstruction, to tone and syllable-initial consonant clusters .

Stefan Strelcri: : Catalogue of Ethiopian manuscripts of the Wellcome Institute of the History of Medicine in London

A. Teeuw: The impact of Balai Pustaka on modern Indonesian literature 
A. S. Tritron: The healing art and the limits of change in nature according to Ibn Hazm

Edward UllendorfF: Some early Amharic letters

\section{OBITUARIES}

William Foxwell Albright .

Ethel Stefana, Lady Drower

Sir Hamilton Alexander Roskeen Gibb .

\section{REVIEWS AND SHORT NOTICES}

Ihsan Abbas (ed.) Das biographische Lexikon des Salähaddin Halī ibn Aibakaṣ-Safadi.

Teil 7. By T. M. Johnstone

R. A. Adeleye: Power and diplomacy in Northem Nigeria, 1804-1906. By Mervy v Hisketr

S. Agesthialingom and S. V. Shanmugam : The language of Tamil inscriptions, 1250-1350 A.D. By J. R. MaRR

Aziz Ahmad: An intellectual history of Islam in India. By P. HARMY . . . .

W. E. D. Allen (ed.) and Anthony Mango (tr.): Russian embassies to the Georgian kings (1589-1605). By M. E. Y $\mathrm{APP}$

Edward Allworth : Nationalities of the Soviet East: publications and writing systems.

Ara Altun: Mardin'de Türk devri mimarisi. By GEza FehérvAri . .
Behramgore Tahmuras Anklesaria (ed. and tr.): The Pahlavi Rivāyat of Aturfarnbag and Farnbag-srōśs. By MARY BoYCe

Michiko Yamaguchi Aoki (tr.): Izumo fudoki. By C J. Duvs " ‘

Mildred Archer: British drawings in the India Office Library. By J. BURTON-PAG

Edwin Ardener (ed.) : Social anthropology and language. By BRUce IrghaM . . $\quad 444$

R. E. Asher and R. Radhakrishnan (comp.): A Tamil prose reader. By J. R. MARR $\quad 435$

Oktay Aslanapa : Turkish art and architecture. By Simon DigBY $\quad$. . . . $\quad$. 688 Muhammad Naguib al-Attas: The mysticism of Hamzah Fansūrī. By N. G. PHILLIrs . 209

H. W. Bailey: Zoroastrian problems in the ninth-century books. Reprinted (with new introduction and index). By Peter Khoroche . . . . . . . . . . . . . . . 432 Bali: further studies in life, thought, and ritual. By C. vox Fürer-HAlMeNdorf . . $\quad 209$

Richard Barnhart : Marriage of the Lord of the River: a lost landscape by Tung Yüan. By WiLliam WaTSON

A. Barthélemy : Dictionnaire arabe-français. Dialectes de Syrie: Alep, Jamas. Liban, Jérusalem. Fascicule complémentaire. By T. M. Johnstons . . . . . . . 429

John Beattie : The Nyoro state. By P. H. Gulliver $\quad . \quad$. . . . . . $\quad$. 189

K. D. Bhargava (ed.): Descriptive list of secret department records. Vol. 1 : 1776-80. By K. A. BAJLLA'TCHE'T

Pratipal Bhatia: The Paramäras (c. 800-1305 A.D.). By Wendy Doniger O'Flaherty

H. C. Bhayani and M. C. Modi (ed.): Haribhadra's Neminähacariya. Vol. I. By T. Bonkow

Durong Thanh Binh: A tagmemic comparison of the structure of English and Vietnamese. sentences. By P.J. Hovey

(. E. Bosworth (ed.): Iran and Islam: in memory of the late ladimir Minorsky. By P. M. HoL'T

Oscar Botto (ed.): Storia delle letterature dOriente. By J. Brough . . . . .

Denise Bouche: Les villages de liberté en Afrique noire française, 1887-1910. By D. H. JONES

Célestin Bouglé: Essays on the caste system. By C. SHACKLE

Raymond A. Bowman: Aramaic ritual texts from Persepolis. By J. B. SEGA.

Ilary Boyce and Ilya Gershevitch (ed.): $\mathbb{W}$. B. Henning memorial volume 8 432 
William M. Brinner and Mounah A. Khouri (ed. and comp.): Readings in modern Arabic literature. Pt. one. By R. C. Ostue

C. C. Brown (tr.): Sĕjarah Mĕlayu. By Russsel Jones

Bulletin of the Faculty of Arts, University of Riyad. Vol. 1. By P. M. Hout .

Briton Cooper Busch: Britain, India, and the Arabs, 1914-1921. By E. R. J. Owev

Rand Castile: The Way of Tea. By Kenneth Strong

E. Cerulli and others (ed.): al-Idrīsi: Opus geographicum, sive 'Liber ad eorum delectationem qui terras peragrare studeant ..... Fasciculus primus. By C. F. BECKINGHAM

K. N. Chaudhuri (ed.): The economic development of India under the East India Company, 1814-58. By W. J. Macpherson

Cheng Chi-hsien: Analyse formelle de l'œuvre poétique d'un auteur des Tang, Zhang Ruo-xu. By A. C. Graham

Abner Cohen : Custom and politics in urban Africa: a study of Hausa migrants in Yoruba towns. By D. H. Jones

Jerome Alan Cohen (ed.): Contemporary Chinese law: research problems and perspectives. By A. R. Droks

Marcel Cohen: Traité de langue amharique (Abysinie). Seconde édition.

Robert O. Collins: Land beyond the rivers: the Southern Sudan, 1898-1918. By GABRIEL WARBURG

M. A. Cook (ed.): Studies in the economic history of the Middle East, from the rise of Islam to the present day. By Frirz STEPPAT

Corpus inscriptionum iranicarum. Pant II. Inscriptions of the Seleucid and Parthian period and of eastern Iran and Central A sia. [Vol.v.] Saka documents. Plates. Portfolio v. By Peter Khoroche

Corpus inscriptionum iranicarum. Part1II. Pahlavi inscriptions. Vol. vI. Seals and coins. Plates. Portfolio II. By Peter Khoroche.

E. Cotran and N. N. Rubin (ed.): Readings in African law. By JAmes S. READ .

N. J. Coulson: Succession in the Muslim family. By David PearL

Albert M. Craig and Donald H. Shively (ed.): Personality in Japanese history. By W. G. BEASLEY

Herrlee G. Creel : The origins of statecraft in China. Vol. one. By Michaet Loewe.

Michael Crowder (ed.): West African resistance. By Mervyn HISkEtT

Kwame Yeboa Daaku : Trade and politics on the Gold Coast, 1600-1720. By D. H. Jones

Bruno Dagens (ed. and tr.): Mayamata: traité sanskrit d'architecture. Première partie. By J. R. MaRR

David Dalby (ed.): Language and history in Africa. By Robert Hetzron . . .

Ahmad Hasan Dani : Peshawar, historic city of the Frontier. By A. D. H. Brvar . $\quad 437$

U. N. Day: The Mughal government, A.D. 1556-1707. By P. HARDY . . . $\quad$. 438

Rafe De Crespigny (tr.): The last of the Han. By Mrchate Lowwe . . . . $\quad 176$

Sven Dedering (ed.): Das biographische Lexikon des Salāhaddīn Halīl ibn Aibak ass-Safadī. Teil 5. By T. M. Johnstone . . . . . . . . . . . . . . . . $\quad$. 427

James Dickie (ed.): The Diwān of Ibn Shuhaid al-Andalusi. By James T. Monros $\quad 144$

Glen Dudbridge: The Hsi-yu chi. By D. E. Pollard _. . . . . . . . . $\quad 177$

D. M. Dunlop: Arab civilization to A.D. 1500. By R. C. Ostle . . . . . $\quad .429$

Marguerite Dupire: Organisation sociale des Peul. By P. H. Gulliver _ . $\quad .424$

H. Byron Earhart: A religious study of the Mount Haguro sect of Shugendō. By CarmeN BLACKER

Elke Eberhard : Osmanische Polemikgegen die Safawiden im 16. Jahrhundert nach arabischen Handschriften. By V. J. PARRY

Wolfram Eberhard: Studies in Chinese folklore and related essays.

R. Y. Ebied: Bibliography of mediaeval Arabic and Jewish medicine and allied sciences. By J. N. Matтoch

Robert B. Edgerton: The individual in cultural adaptation: a study of four East African peoples. By Paul Spencer

I. E. S. Edwards and others (ed.): Early history of the Middle East. By D. J. WISEMAN

M. B. Emeneau : Dravidian comparative phonology. By J. R. MatRR 
H. Epstein : Domestic animals of China. By Exprmon Wrumsox . . . . . 206

Majid Fakhry: A history of Islamic philosophy. By J. N. MArTock . . . . . 198

Charles A. Ferguson: Language structure and language use. By N. V. Ммітн . $\quad$. 682

Allan G. B. Fisher and Humphrey J. Fisher: Slavery and Muslim society in Africa. By IVAN HRBEK

Denys Forrest: Tiger of Mysore: the life and death of Tipu Sultan. By Simon Dig BY

Sidney D. Gamble (ed.): Chinese village plays from the Ting Hsien region (Yang ke hsüan). By Hugh D. R. Baker

Martin R. Ganzglass: The penal code of the Somali Democratic Republic. By A. X. Allotr

Rutherford J. Gettens and others: Two early Chinese bronze weapons with meteoritic iron. blades. By William Wa'rson

Suresh Chandra Ghosh : The social condition of the British community in Bengal, 1757-1800. By P. J. Marshall

George Giacumakis, Jy.: The Akkadian of Alalah. By J. D. Hawnixs . . .

H. A. R. Gibb (tr.): The travels of Ibn Battutata, A.D. 1325-1354. Vol. II. By R. B. SERJEANT

John C. I. Gibson: Textbook of Syrian Semitic inscriptions. Vol. I. By Giovanni GaRBini

Lancelot Giles: The siege of the Peking legations. By I. H. NisH

Daniel Gimaret (tr.): Le livre de Bilawhar et Büdāsf selon la version arabe ismaélienne. By D. M. LANG

Ignaz Goldziher : The Zăhiris. By W. Montgomery WatT . . . . .

Richard F. Gomblich : Precept and practice: traditional Buddhism in the rural highlands of Ceylon. By C. H. B. Reynolos

Godfrey Goodwin : A history of Ottoman architecture. By Antory Hutr . . . .

Jack Goody : Technology, tradition, and the state in Africa. By A. N. Alcotr . .

Hans L. Gottschalk and others: Die Kultur des Islams. By Srmon DigBY . . .

Hans-Jürgen Greschat and Herrmann Jungraithmayr (ed.): Wort undReligion: Kalima na dini. Studien zur Afrikanistik, Missionswissenschaft, Religionswissenschaft. By Michael, Maxn

J.S. Grewal: Muslim rule in India: the assessments of British historians. By SIMoN DigBY François Gros and R. Nagaswamy: Uttaramērür. By J. R. MARR

G. E. von Grunebaum (ed.): Theology and law in lslam. By J. N. D. ANderson . .

Tlrich Haarmann : Quellenstudien zur frühen Mamlukenzeit. By V. J. Parry . .

Ulrich Haarmann (ed.): Die Chronik des Ibn ad-Dawädāri. Achter Teil. By P. M. HoLT

Robert M. Haddad : Syrian Christians in Muslim society: an interpretation. By P. M. HouT

Michael Hahn : Lehrbuch der klassischen tibetischen Schriftsprache. By W. Srmox . .

Gordon MacKay Haliburton: The prophet Harris. By HumphreY J. Fisher . .

David E. Hall (ed.) : Union catalogue of Asian publications, 1965-1970. By StaNLEY SUTTON.

John G. Hangin : A concise English-Mongolian dictionary . . . . . . . .

Yen-ping Hao: The comprador in nineteenth century China. By CHRistopher Howe

Tom Harrisson and Stanley J. O'Connor: Gold and megalithic activity in prehistoric and recent west Borneo. By I. C. GLover.

Yūsuf Faḍl Hasan (ed.): Muhammad al-Nür b. Dayf Allāh : Kitäb al-tabaqāt fi khuṣūs

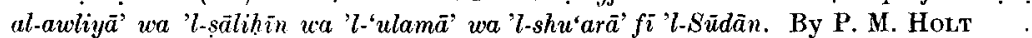

Oi-kan Yue Hashimoto: Studies in Yie dialects, 1. By Hugh D. R. BAKer. . .

John A. Haywood: Modern Arabic literature, 1800-1970. By R. C. OsTLE . . .

IV. B. Henning: A fragment of a Khwarezmian dictionary. By Peter KHoroche. .

Matthias Hermanns: Schamanen-Pseudoschamanen. By C. R. BAwden . . . 393

Hans Hickmann and Wilhelm Stauder : Orientalische Musik. By O. Wright . $\quad . \quad 149$

A. H. Hill (tr.): The Hikayat Abdullah. By E. C. G. BarreTT . . . . $\quad 442$

D. R. Hill: The termination of hostilities in the early Arab conquests, A.D. 634-656. By Patricia Chone 
J. Hillier (comp.): The Harari collection of Japanese paintings and drawings. Vols. 1-2. By B. W. Robinsoy

P. M. Holt and others (ed.): The Cambridge history of Islam. By R. C. OstuE

George F. Hourani : Islamic rationalism: the ethics of 'Abd al-Jabbār. By M. C. Lyons .

Fred W. Householder: Linguistic speculations. By R. H. RoBiss

Tso-liang Hsiao: The land revolution in China, 1930-1934: a study of documents. By C. A. CuRwen .

Immanuel C. Y. Hsü (ed.): Readings in modern Chinese history. By HUGH D. R. BAKER

Helmut Humbach and Kaikhusroo M. JamaspAsa (ed. and tr.) : Vae日ä Nask: an apocryphal text on Zoroastrian problems. By Peter KHoRoche

Index des mots de la littérature tamoule ancienne. Vols. II (ka-tau)-III (na-na). By J. R. Marr

John Irwin and Katharine B. Brett: Origins of chintz. By J. Burton-PAGE . .

K. Ishwaran (ed.): Change and continuity in India's villages. By C. voN FürERHAIMENDORF

Hubert Th. Th. M. Jacobs (ed. and tr.): Atreatise on the Moluccas (c. 1544). By D. K. BASSETT .

N. A. Jairazbhoy : The rägs of North Indian music. By L. E. R. PlckeN

Kaikhusroo M. JamaspAsa and Helmut Humbach (ed. and tr.) : Pursǐ̌ñihā. By D. N. MacKenzie

A. Jamme: Sabaean inscriptions from Mahram Bilqîs (Mârib). By A. F. L. Beeston .

Klaus L. Janert and $\mathrm{N}$. Narasimhan Poti (comp.) : Indische und nepalische Handschriften, Teil 2

N. A. Jayawickrama (ed. and tr.): The chronicle of the Thüpaand the Thüpavamsa By K. R. Norman .

Journal of Arabic Literature. Vols. I-II

Journal of Tamil Studies. Vol. 1, No. 1. By J. R. MARR

Robert W. July: A history of the African people. By Shula Marks

Harold L. Kahn : Monarchy in the emperor's eyes. By MaRK Elvin . . . . 402

A. S. Kanya-Forstner: The conquest of the Western Sudan: a study in French military imperialism. By D. H. Jones .

Diana L. Kao: Structure of the syllable in Cantonese. By Hugh D. R. BAKER . . 657

Hasan S. Karmi : al-Manār: an English-Arabic dictionary. By T. M. Johnstone $\quad 629$

Donald Keene (tr.): Chüshingura. By C. J. Dons

Fathalla Kholeif (ed.): Kitāb al-tawhìd: Abū Manșūr Muhammad ibn Muhammad ibn Mahmüdal-Mäturidi al-Samarqandi. By J. N. MatTock

Mounah A. Khouri : Poetry and the making of modern Egypt (1882-1922). By R. C. OstLe

V. G. Kiernan (tr.): Poems by Faiz. By C. ShackLe

Anthony Kirk-Greene and Paul Newman (tr.): West African travels and adventures. By Mervyn HisketT

Sita Ram Kohli (ed.): Fort William-India House correspondence and other contemporary papers relating thereto (military series). Vol. $x x_{1}: 1797-1800$. By K. A. BaLLhatcheT

David Kopf : British Orientalism and the Bengal renaissance. By K. A. Balluatchet

Manfred Kudlek and Erich H. Mickler : Solar and lunar eclipses of the ancient Near East from 3000 B.c. to 0 with maps. By F. R. Stephenson .

Ernst Kühnel : Islamic arts. By B. W. RoBrnson

Philip A. Kuhn : Rebellion and its enemies in late imperial China. By HUGH D. R. BAKER

Hermann Kulke: Cidambaramāhätmya. By J. R. MARR

Adam Kuper: Kalahari village politics. By David Parkin

M. A. Laird (ed.): Bishop Heber in northern India. By Geoffrey PaRRINder .

H. M. Lambert: Gujarati language course. By D. F. Pocock . . .
Étienne Lamotte (tr.) : Le traité de la grande vertu de sagesse de Nāgärjuna (Mahäprajñăpäramitā́ästra). Tom. III. By J. BROUGH .

David Marshall Lang: Armenia: cradle of civilization 
J. Langhade (ed. and tr.) and M. Grignasehi (ed.) : al. Fārābi: deux ouvrages inédits sur la

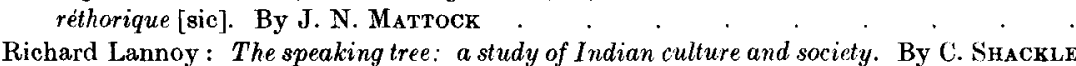

PAGE

Franz László: Die Parallelversion der Manusmrti im Bhaviṣyapurāna. By Peter KHOROCHE

J. D. Latham and W. F. Paterson: Saracen archery, By R. B. SERuturn

Robert H. G. Lee: The Manchurian frontier in Ch'ing history. By C. A. Curwex . , $403^{\circ}$

Raphaela Lewis: Everyday life in Ottoman Turkey. By S. A. Skilliter _ . . . . 199

Louis Ligeti (ed.): Histoire secrète des Mongols.-Louis Ligeti : Monuments préclassiques. 1694

Louis Ligeti (ed.): Studia turcica . . . . . . . . . . . . . . $\quad{ } 433$

Ruth Linhart: Ishikawa Takuboku und der japanische Naturalismus. By Kennetu STrong 698

Sepp Linhart : Sozialer Wandel in ländlichen Siedlungen auf Hokkaidō . . . . . $\quad 208$

Donald Presgrave Little: An introduction to Mamlük historiography. By V. J. PARRY 362

Irving Yucheng Lo: Hsin Chi-chi. By JAMes J. Y. LIU . . . . . . . 695

Helene Loebenstein: Katalog der arabischen Handschriften der Österreichischen National. bibliothek. Neuerwerbungen 1868-1968. Teil 1. By T. M. JoHNstone . . . . 430

Maurice Lombard: Études d'économie médiévale. I. By P. M. HoLT . . . . . 430

Gordon H. Luce: Old Burma-early Pagán. By H. L. Sнonto . . . . . . 181

Madeleine Ly-Tio-Fane (ed.): Mauritius and the spice trade. [Yol. 1I.] By K. N. CHAUDHURI

Bonnie S. McDougall : The introduction of Western literary theories into modern China, 1919-1925. By D. E. Poltuard .

Wyatt MacGaffey : Custom and government in the lower Congo. By P. H. Gulliver, 190

R. S. MeGregor (ed.): Exercises in spoken Hindi. By S. C. R. Weichtman . . $\quad 167$

Pierre A. MacKay : Certificates of transmission on a manuscript of the Maqāmat of Hariri. By R. B. SerJeant .

D. N. MacKenzie: A concise Pahlavi dictionary. By Petre Khoroche . . . 160

Bimanbehari Majumdar : Krsna in history and legend. By R. D. Gupra . . . 168

Dalsukh Malvania (ed.): Ágamic index. Vol. 1. Prakrit proper names. Part 1. By W. B. Bollée

David G. Mandelbaum : Society in India. By C. von Fürer-HaImendorf . . $\quad$. 389

Jacques Maquet : Power and society in Africa. By Padl Spencer . . . . . 444

Mare Luso-indicum. 1. By C. F. BeckinghaM . . . . . . . . . $\quad 202$

David G. Marr : Vietnamese anticolonialism, 1885-1925. By R. B. SMrTH . . 412

M. Șaghir Hasan Ma'sūmi (tr.) : Imăm Räzì's 'ilmal-akhlāq. By J. N. MAtrock 364

Noel Matthews and M. Doreen Wainwright (comp.): A guide to manuscripts and documents in the British Isles relating to Africa. By RIOHARD GRAY

Curt Maury: Folk origins of Indian art. By J. R. MarR

Jacques-Ghislain de Maussion de Favières : Damas, Bagdad

L. A. Mayer: Mamluk playing cards. By GEza Fehérvári

Georges Mazenot: La Likouala-Mossaka. By David Birmingham

Dimitri Meeks and others : Génies, anges et démons, By S. G. F. Brandox . . . 194

R. N. Mehta: Excavation at Nagara. By J. Burton-Page . . . . . . . $\quad 202$

R. N. Mehta and S. N. Chowdhary : Excavation at Jokha. By J. M. STRuB . . . 436

George C. Miles: The coinage of the Arab Amirs of Crete. By A. D. H. Brvar _ $\quad 151$

J. V. G. Mills (tr.): Ma Huan: Ying-yai sheng-lan. By C. A. Cunwen . . $\quad 400$

Richard H. Minear: Japanese tradition and Western law: emperor, state, and luw in the thought of Hozumi Yatsuka. By R. L. Sims

Gerald Morgan : Ney Elias: explorer and envoy extraordinary in high Asia. By AlastaIR LAMB

Ivan Morris (tr.): As I crossed a bridge of dreams. By C. J. DunN . . . . .

Ramon H. Myers: The Chinese peasant economy. By HoGH D. R. BAKER . .
Gustav Nachtigal : Sahara and Sudan. Vol.four. Translated...by Allan G. B. Fisher and Humphrey J. Fisher with Rex S. O'Fahey. By G. E. Wickens

Tilman Nagel: Cntersuchungen zur Entstehung des abbasidischen Kalifates. By CuaddE CAHEN 
Prem Narain: Press and politics in India, 1885-1905. By J. M. Compton . . . 693

Joseph Naveh: The development of the Aramaic script. By Sebastian Brock . $\quad 136$

M. A. Nayeem : The philatelic and postal history of Hyderabad. Vol. one. History of postal administration in Hyderabad. By Simon DigBY.

Joseph Needham: Science and civilisation in China. Vol. 4. Pt. IH. By Muchael Loewe Jacob Neusner: The Rabbinic traditions about the Pharisees before 70 . By Lours J $\mathrm{J}_{\mathrm{AcoBS}}$ C. S. Nicholls: The Swahili coast. By W. H. WhITELEY

F. G. Notehelfer: Kótoku Shūsui: portrait of a Japanese radical. By W. G. BEAsLeY Paul Nwyia: Exégése coranique et langage mystique. By W. Mon'roomery Watt. . Cüneyt OOlçer: Sultan Mahmud II zamanında darp edilen Osmanl madeni paraları. By V. J. Parry

D. A. Ol'derogge (ed.): Strany i narody Vostoka. Vyp. x. Srednyaya i tsentral'naya Aziya. By A. D. H. BivaR.

Rudi Paret: Der Koran: Kommentar und Konkordanz. By A. F. L. Beestow . . Denise Paulme (ed.): Classes et associations d'âge en Afrique de l'Ouest. By G. I. Jones J. D. Pearson (comp.): Oriental manuscripts in Europe and North America. By P. M. HolT J. D. Pearson and Ruth Jones (ed.): The bibliography of Africa. By Michatel Mann . P. W. Pestman (ed.): Acta orientalia neerlandica

Giovanni Pettinato: Das altorientalische Menschenbild und die sumerischen und akka. dischen Schöpfungsmythen. By W. G. LamBerT

Arthur Phillips and Henry F. Morris : Marriage laws in Africa. By PAuL Spencer

Suranad Kunjan Pillai (ed.): Malayalam lexicon. Vols. I-II. By R. E. Asher . $\quad$. 378

H. J. Polotsky : Collected papers. By Edward UlumndorfF . . . . . . . . $\quad 623$

Margaret Priestley: West African trade and Coast society: a family study. By D. H. Jowws 210

I. de Rachewiltz: Papal envoys to the Great Khans. By C. F. Beckingham . . . 204

Jutta Rall : Die vier grossen Medizinschulen der Mongolenzeit . . . . . . . $\quad 440$

Niharranjan Ray: The Sikh Gurus and the Sikh society: a study in social analysis. By C. SHACKLE

D. S. Richards (ed.): Islam and the trade of Asia. By Derek Latham .

Leo E. Rose: Nepal: strategy for survival. By D. J. MatThews .

John M. Rosenfeld and Shūjirō Shimada : Traditions of Japanese art: selections from the Kimiko and John Powers collection. By Margaret Medley .

Erwin I. J. Rosenthal : Studia semitica

N. N. Rubin and E. Cotran (ed.): Annual survey of African law. Fol. 1-1967. By ALAN Milner

Ralph Russell and Khurshidul Islam (ed. and tr.): Ghalib, 1797-1869. Vol.t. By Srmos DrgBY

Armas Salonen: Die Fischerei im alten Mesopotamien nach sumerisch-akkadischen Quellen. By J. N. Postante

Julio Samsó Moya: Estudios sobre Abū Nậ̣ Manşūr b. 'Alī b. 'Irāq. By Farida AbuHaIdar .

Sañs-rgyas bstan-'jin and Alexander W. Macdonald (ed.): Documents pour l'étude de la religion et de l'organisation sociale des Sherpa.

Ruth Fuller Sasaki and others (tr.): The recorded sayings of layman P'ang. By H. INAGAKI J. J. Saunders: The history of the Mongol conquests. By C. F. Beckingham

Barbara Schäfer: Beiträge zur mamlukischen Historiographie nach dem Tode al-Malik an-Nāsirs. By J. Hawting

Edward H. Schafer: Shore of pearls. By William Watson . . . . .

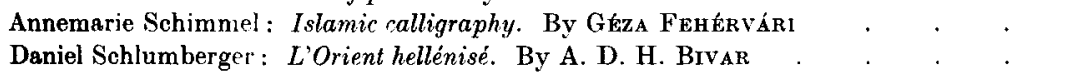

Gilbert Donald Schneider: West African Pidgin-English. By D. W. ArnotT . . H. G. Schulte Northolt: The political system of the Atoni of Timor. By M. C. RICKLEFs 
Thomas A. Sebeok (ed.): Current trends in linguistics. Vol. 7. Linguistics in sub-Saharan Africa. By Hazel Carter

M. A. Shaban: The 'Abbãsid revolution. By V. J. PARRY . . . . . . . 147

M. A. Shaban : Islamic history, A.D.600-750 (A.H.132). By D. SoordeL . . . . 358

P. L. Shinnie (ed.): The African iron age. By David Birmingram . . . $\quad 701$

H. L. Shorto: A dictionary of the Mon inscriptions from the sixth to the sixteenth centuries. By C. HooykaAs

Ratna Nagesha Shriyan: A critical study of Mahäpurāna of Puspadanta. By T. BurRow Suzanne Siauve: Les hiérarchies spirituelles selon l'Anuvyākhyāna de Madhva. By J. C.

WRIGHT .

Iqtidar Husain Siddiqui : History of Sher Shah Sur. By Simon DigBY .

Purushottam Singh: Burial practices in ancient India. By I. C. Glover

B. P. Sinha and Lala Aditya Narain: Pätaliputra excavation, 1955-56. By J. M. STRUB

B. P. Sinha and Sita Ram Roy: Vaiśáli excavations, 1958-1962. By J. M. STru B . Chittaranjan Sinha: The Indian civiljudiciary in making, 1800-33. By K. A. Ballhatchet W. H. Sleeman : Sleeman in Oudh. By Simon DigBy .

John Masson Smith, Jr.: The history of the Sarbadār dynasty, 1336-1381 A.D., and its sources. By A. K. S. Lambton.

Robert Smith: Kingdoms of the Yoruba. By D. H. Jones . . . . . .

Richard Snailham: The Blue Nile revealed. By A. K. Inving . . . . .

South Asia: Journal of South Asian Studies. No. 1. By K. A. Ballhatchet . .

Otto spies and Horst Müller-Bütow (tr.): Anatomie und Chirurgie des Schädels, insbesondere der Hals-, Nasen- und Ohrenkrankheiten nach Ibn al-Quff. By J. N. Matтock

Melford E. Spiro: Buddhism and society: a great tradition and its Burmese vicissitudes. By JoHN OKELL

Jürgen Kurt Stark: Personal names in Palmyrene inscriptions. By A. K. Irvin E

Jack Stauder: The Majangir: ecology and society of a southwest Ethiopian people. By A. K. S. LAMBTON

John J. Stephan: Sakhalin: a history. By R. L. Sims

Jaroslav Stetkevych: The modern Arabic literary language: lexical and stylistic developments. By A. F. L. Benston

Abdus Subhan (ed.): The Tárikh-i-Bangála-i-Mahábatjangí (an eye-witness account of Nawáb'Alivardi Khán of Bengal and his times) of Yúsuf'Ali Khán. By P. HARdy

Dae-sook Suh (tr. and comp.): Documents of Korean Communism, 1918-1948. By W. E. SKILLEND

Daisetz T. Suzuki : Sengai, the Zen master. By Kenneth Strong

A. Teeuw and D. K. Wyatt (ed. and tr.): Hikayat Patani. By E. C. G. Barretr .

Dagmar Thiele: Der Abschluss eines Vertrages: Diplomatie zwischen Sung- und ChinDynastie, 1117-1123.

Jacqueline M. C. Thomas (ed. and tr.): Contes, proverbes, devinettes ou énigmes, chants et prières ngbaka-ma'bo (République Centrafricaine). By G. InNes

Richard C. Thornton: The Comintern and the Chinese Communists, 1928-1931. By DonaLD S. SuTTON

G. L. Tikku : Persian poetry in Kashmir, 1339-1846. By Simon Dig BY

J. Tilakasiri (ed.): Añjali: papers on Indology and Buddhism. By J. C. Wright . .

S. A. I. Tirmizi (ed.) : Persian letters of Ghalib. By Srmon DigBy . . . .

Helmut Töllner : Die türkischen Garden am Kalifenhof von Samarra. By P. M. HoLT

Ferenc Tökei : Genre theory in China in the 3rd-6th centuries. By D. E. Pollard . .

H. N. van der Tuuk: A grammar of Toba Batak. By M. C. Ricklefs _. .

Norihiko Učida: Der Bengali-Dialekt von Chittagong. By JoHN Bouston . . . Morgenländische Gesellschaft. 9./10. Lief. By R. B. Serjearr . . . .

Edward Van Roy : Economic systems of northern Thailand. By P. J. BEE . . .

Laura Veceia Vaglieri and Robrrto Rubinacei (tr.): Scritti scelti di al-Ghazäli. By W. Montgonery Wa'tT 
P. Voorhoeve: Südsumatranische Handschriften. By C. HooykaAs . . . . $\quad$ - 700

Calvert Watkins : Indogermanische Grammatik, hrsg. von Jerzy Kurylowicz. Bd. III; Formenlehre. Erster Teil. By Theodora Bynon . . . . . . . . . . . . 161

William Watson (ed.): Pottery and metalwork in T'ang China. By C. R. BawdeN . $\quad 440$

J. W. Wevers and D. B. Redford (ed.): Essays on the ancient Semitic world. By M. J. SelmaN . . . . . . . . . . . . . . . . . . . 684

W. H. Whiteley (ed.): Language use and social change. By Edwin Ardener . 415

Geoffrey J. Williams: A bibliography of Sierra Leone, 1925-1967. By HuMPHREy J. Fisher 213

John Alden Williams (ed.): Themes of Islamic civilization. By P. M. HoLt . . $\quad .429$

Monica Wilson: Religion and the transformation of society. By Geoffrey Parrinder $\quad 443$

Monica Wilson and Leonard Thompson (ed.): The Oxford history of South Africa. 11. By Anthony Atrore . . . . . . . . . . . . . . . . . 678

William R. Wilson (tr.): Hōgen monogatari . . . . . . . . . . . . . 207

George Woodcock : Into Tibet: the early British explorers . . . . . . . . .204

David Wurfel (ed.): Meiji Japan's centennial: aspects of political thought and action. $1 \mathrm{y}$ W. G. Beasley

Philip B. Yampolsky (tr.): The Zen master Hakuin: selected uritings. By KaNNETH STrong. . . . . . . . . . . . . . . . . . 697

Kunio Yanagita: About ont ancestors-the Japanese family system. By ErMI WatanaBe 208

OTHER BOOKS RECEIVED FOR REVIEW 215, 446, 702

' Under the clear moon '--an Amharic poem . . . . . 706 


\section{EDITORIAL BOARD}

Professor Edward Ullendorfi, M.A., D.Phil, D.Litr., F.B.A. (Chairman)

Professor C. R. Bawdex, M.A., Ph.D., F.B.A.

Professor P. M. Holt, M.A., D.Phil., D.Litt.

Professor C. H. Philips, M.A., D.LrTt., Ph.D.

Professor R. H. Robins, M.A., D.Lit.

Professor H. L. Shorto, M.A.

Professor D. J. Wiseman, O.B.E., M.A., D.Lit., F.B.A., F.S.A. Professor J. C. Wright, M.A., B.A.

Editorial Secretary: Miss D. M. Johnson, M.A. 